\title{
Psychological training of future specialists in physical culture and sports for the activities of a sports coach in higher education institutions
}

\author{
Dmitriieva N.
}

\author{
National Pedagogical Dragomanov University, Kyiv, Ukraine
}

Received: 21.02.2021 Accepted: 20.03.2021

\begin{abstract}
The purpose of the article is to highlight the features of the methodology of psychological training of future specialists in physical culture and sports for the activities of a sports coach and its implementation in higher education institutions. To achieve this goal, the analysis and generalization of scientific literature on issues related to the psychological training of future professionals in physical culture and sports to the activities of a sports coach; the categorical apparatus of the research was formulated and the object, subject, concept and general hypothesis of the research were determined. Methods of psychological training of future specialists in physical culture and sports for the activities of a sports coach in higher education institutions involves a consistent movement of educational levels: the level of motivation for training for the activities of a sports coach, the level of theoretical experience, the level of practical experience. Implementation of the developed methods of psychological training of future specialists in physical culture and sports to the activities of a sports coach was carried out during theoretical and practical classes in the disciplines «Introduction to the specialty», «Theory and methods of physical education», «Theory and methods of gymnastics», "Fundamentals sports training», "Olympic and professional sports» and coaching practice. A necessary technological condition for the implementation of the leading idea is the observance of strict sequence in the assimilation of educational material: the development of the studied information, the formation of skills to use this material, the formation of skills to act adequately in professional activities. The organization of psychological training of future specialists in physical culture and sports for the activities of a sports coach was carried out during practical classes in professional disciplines and includes the following components: forms of system of formation of psychological readiness of future specialists in physical culture and sports for sports coach activities, interactive educational technologies, business games that involve future professionals in physical therapy and occupational therapy professional tasks and responsibilities, problem-oriented learning, project-oriented learning, team-oriented learning, means of physical education and sports training, textbooks, manuals, test tasks, information tools and communication technologies.
\end{abstract}

Key words: professional training, psychological training of future specialists, physical culture and sports, professional training in higher education institutions, activity of a sports coach.

\section{Психологічна підготовка майбутніх фахівців з фрізичної культури і спорту до діяльності тренера з виду спорту у закладах вищої освіти}

\author{
Дмітрієва Н. С.
}

Національний педагогічний університет імені М. П. Драгоманова, Київ, Україна

\begin{abstract}
Анотація. Метою статті $є$ висвітлення особливостей методики психологічної підготовки майбутніх фрахівців 3 фізичної культури і спорту до діяльності тренера з виду спорту та її впровадження у закладах вищої освіти. Для досягнення мети здійснено аналіз та узагальнення наукової літератури з питань, пов'язаних 3 психологічною підготовкою майбутніх фахівців з фізичної культури і спорту до діяльності тренера 3 виду спорту; формулювався категоріальний апарат дослідження та визначалися об'єкт, предмет, концепція та загальна гіпотеза дослідження. Методика психологічної підготовки майбутніх фрахівців з фізичної культури і спорту до діяльності тренера з виду спорту у закладах вищої освіти передбачає послідовний рух за навчальними рівнями: рівень мотивації до професійної підготовки до діяльності тренера з виду спорту, рівень теоретичного досвіду, рівень практичного досвіду. Впровадження розробленої методики психологічної підготовки майбутніх фахівців з фізичної культури і спорту до діяльності тренера з виду спорту здійснювалося під час теоретичних та практичних занять з дисциплін «Вступ до спеціальності», «Теорія і методика фізичного
\end{abstract}

Corresponding Author: Dmitriieva Nikol Subkhanivna. Tel. +38(067)765-61-99. E-mail: nikolestern@ukr.net. National Pedagogical Dragomanov University, Pyrogova st., 9, Kyiv, Ukraine, 01601.

Відповідальний автор: Дмітрієва Ніколь Субханівна. Tel. +38(067)765-61-99. E-mail: nikolestern@ukr.net. Національний педагогічний університет імені М. П. Драгоманова, вул. Пірогова, 9, м. Київ, Україна, 01601. 
виховання», «Теорія і методика гімнастики», «Основи спортивного тренування», «Олімпійський і професійний спорт» та проведення тренерської практики. Необхідною технологічною умовою реалізації провідної ідеї $\epsilon$ дотримання суворої послідовності в засвоєнні навчального матеріалу: освоєння досліджуваної інформації формування умінь використовувати цей матеріал, формування умінь адекватно діяти в умовах професійної діяльності. Організація психологічної підготовки майбутніх фахівців з фізичної культури і спорту до діяльності тренера з виду спорту здійснювалося під час практичних занять з фахових дисциплін включає такі складові: форми системи формування психологічної готовності майбутніх фахівців з фізичної культури і спорту до діяльності тренера з виду спорту, інтерактивні освітні технології, ділові ігри, які передбачають виконання майбутніми фахівцями з фізичної терапії та ерготерапії професійних завдань і обов'язків, проблемно орієнтоване навчання, проектно орієнтоване навчання, командно орієнтоване навчання, засоби фізичноо виховання та спортивної підготовки, підручники, навчальні посібники, тестові завдання, засоби інформаційних та комунікаційних технологій.

Ключові слова: професійна підготовка, психологічна підготовка майбутніх фрахівців, фізична культура і спорт, професійна підготовка у закладах вищої освіти, діяльність тренера з виду спорту.

\title{
Психологическая подготовка будущих специалистов по физической культуре и спорту к деятельности тренера по виду спорта в в высших учебных заведениях
}

\author{
Дмитриева Н. С. \\ Национальный педагогический университет имени М. П. Драгоманова, Киев, Украина
}

\begin{abstract}
Аннотация. Целью статьи является освещение особенностей методики психологической подготовки будущих специалистов по физической культуре и спорту к деятельности тренера по виду спорта и его внедрение в в высших учебных заведениях. Для достижения цели осуществлен анализ и обобщение научной литературы по вопросам, связанным с психологической подготовкой будущих специалистов по физической культуре и спорту к деятельности тренера по виду спорта; формулировался категориальный аппарат исследования и определялись объект, предмет, концепция и общая гипотеза исследования. Методика психологической подготовки будущих специалистов по физической культуре и спорту к деятельности тренера по виду спорта в учреждениях высшего образования предусматривает последовательное движение по учебным уровням: уровень мотивации к профессиональной подготовке к деятельности тренера по виду спорта, уровень теоретического опыта, уровень практического опыта. Внедрение разработанной методики психологической подготовки будущих специалистов по физической культуре и спорту к деятельности тренера по виду спорта осуществлялось при теоретических и практических занятий по дисциплинам «Введение в специальность», «Теория и методика физического воспитания», «Теория и методика гимнастики», «Основы спортивной тренировки», «Олимпийский и профессиональный спорт» и проведения тренерской практики. Необходимой технологической условием реализации ведущей идеи является соблюдение строгой последовательности в усвоении учебного материала: освоение изучаемой информации формирования умений использовать этот материал, формирования умений адекватно действовать в условиях профрессиональной деятельности. Организация психологической подготовки будущих специалистов по физической культуре и спорту к деятельности тренера по виду спорта осуществлялось во время практических занятий по специальным дисциплинам включает следующие составляющие: формы системы формирования психологической готовности будущих специалистов по физической культуре и спорту к деятельности тренера по виду спорта, интерактивные образовательные технологии, деловые игры, которые предусматривают выполнение будущими специалистами по физической терапии и эрготерапии профессиональных задач и обязанностей, проблемно ориентированное обучение, проектно ориентированное обучение, командно ориентированное обучение, средства физически и воспитания и спортивной подготовки, учебники, учебные пособия, тестовые задания, средства информационных и коммуникационных технологий.

Ключевые слова: профессиональная подготовка, психологическая подготовка будущих специалистов, физическая культура и спорт, профессиональная подготовка в высших учебных заведениях, деятельность тренера по виду спорта.
\end{abstract}

\section{Introduction}

The priority tasks of the national system of higher education are: providing conditions for mastering the system of knowledge and preparing young people for further professional activity, graduation of competitive specialists in the labor market. This involves educating students during their studies at a higher education 
institution independent of the teacher's practical skills of finding the necessary information, the formation of high responsibility of the student for the results of their educational, scientific and creative activities $[3,19]$.

A specialist in physical culture and sports must be able to learn and implement the achievements of world civilization in their professional activities, master the modern methodology of justifying decisions and choosing a strategy based on universal values, personal, social, state and industrial interests, and be able to adapt to market at the level of participation in the work of various organizations [23].

The latest pedagogical technologies focus the system of higher physical education on the training of graduates with professional competence and skills to navigate the labor market, to present themselves favorably, to compete with other job applicants $[13,24]$. The solution to the problem of professional activity of future specialists in physical culture and sports is based on a competency-based approach, in which the professional and personal characteristics of the graduate are associated with the personnel needs of Olympic and professional sports [26, 27].

The quality of higher physical education is important for the effective professional training of future specialists in physical culture and sports, which determines the degree of their readiness for the activity of a sports coach.

The variety of professional duties and a wide range of pedagogical tasks solved by the coach place increased demands on his activities and personality $[2,15,18]$. With a superficial acquaintance with the work of a coach in sports, it may seem that we are talking only about preparing athletes for performances at competitions of various ranks [1]. The task of the coach is not only the sports achievements of an athlete, but also the upbringing of a comprehensively developed, educated person, capable of using the cultural heritage of society and self-development. The implementation of this task requires resolving the contradiction between the need to assimilate sports experience and knowledge of previous generations, the culture they created, learn to build on their basis their professional activities and behavior, on the one hand, and the importance of their constant improvement, on the other.

Analysis of research in the field of sports psychology $[16,17]$ showed that, despite the interest in the role of a coach in training an athlete, many issues of psychological preparation of future specialists in physical culture and sports for coaching remain unexplored.

The aim of this paper is to highlight the features of the methodology of psychological training of future specialists in physical culture and sports to the activities of a sports coach and its implementation in higher education institutions.

\section{Materials and Methods}

Experimental work was considered by us as a method of making changes in the process of professional training, designed to obtain an educational effect, followed by verification.

The organization of research work took into account such conditions for the effectiveness of its implementation as: analysis of the problem in pedagogical theory and practice of higher education institutions for psychological training of future specialists in physical culture and sports to the activities of a sports coach; concretization of the hypothesis based on the study of the problem in the theory and methodology of vocational education; the need to exchange information between the subjects of the pedagogical process.

The analysis and generalization of the scientific literature on issues related to the psychological training of future specialists in physical culture and sports for the activities of a sports coach; the categorical apparatus of the research was formulated and the object, subject, concept and general hypothesis of the research were determined.

The object of research is the psychological training of future specialists in physical culture and sports for the activities of a sports coach in higher education institutions.

The subject of the research is the method of psychological training of future specialists in physical culture and sports for the activity of a sports coach in higher education institutions.

The concept of the study is based on interrelated methodological, theoretical and methodological concepts.

The leading idea of the study is that the psychological training of future specialists in physical culture and sports for the activities of a sports coach in higher education is based on the organization of the training process, which provides it with active teaching methods, modern information and communication technologies 
and interaction between teachers and students, takes into account the principles of variability in the choice of content and forms of education, cultural relevance, context, taking into account the individual characteristics of the student's development and his physical fitness, continuity and prospects, creativity; and also aims to form the psychological readiness of future professionals in physical culture and sports to work as a sports coach.

The implementation of this leading idea of the study requires taking into account the positive achievements of domestic and foreign experience of psychological training of future specialists in physical culture and sports to the activities of a sports coach in higher education.

The methodological concept of the research reflects the relationship of methodological approaches at the philosophical, general scientific, specific scientific and methodological levels.

At the philosophical level of the methodology the principles of cognition are analyzed and a categorical apparatus of research of the problem of psychological preparation of future specialists in physical culture and sports for the activity of a sports coach in higher education institutions is developed.

The general scientific level of the methodology allows to study the scientific concepts that characterize the process of psychological training of future specialists in physical culture and sports for the activities of a sports coach in higher education institutions.

The specific scientific level of the methodology makes it possible to describe the methods and principles of researching the problem of psychological training of future specialists in physical culture and sports for the activities of a sports coach in higher education institutions.

The main provisions of the system, activity, axiological, culturological, competence, personality-oriented and modular methodological approaches serve as methodological guidelines.

The application of a systematic approach allows to consider the psychological training of future specialists in physical culture and sports for the activities of a sports coach in higher education institutions as a system of complex and multifactorial education, covering teaching and educational activities of teachers and students.

The activity approach allows to consider the basic components of activity of teachers and students from uniform methodological positions and to open the nature of their interaction; to study the peculiarities of the activities of all participants in the pedagogical process through the projection of the general conceptual provisions of the theory of activity; to establish the main factors of personality development of the future specialist in physical culture and sports; to define the process of training future specialists as a continuous change of different types of educational and upbringing work; to build the pedagogical process in accordance with the mastery of the structural components of coaching (goal, motives, actions, analysis of the results achieved).

The implementation of the axiological approach is aimed at determining the procedural features of psychological training of future specialists in physical culture and sports to the activities of a sports coach in higher education, the choice of forms, methods and means of pedagogical interaction to organize the training process.

From the point of view of the culturological approach the consideration in the maintenance of higher education of cultural social experience and achievements in the field of physical culture is provided.

Implementation of the competence approach in the higher education system involves a gradual reorientation from the translation of the necessary set of knowledge to the formation of professional competence, which will allow the graduate to effectively coach in today's multifactorial social, political, market, economic, information and communication space [3]. Improving the quality of psychological training of future specialists in physical culture and sports for the activities of a sports coach in higher education institutions in the context of the competency approach allows to strengthen the applied and professional orientation of education; increase the share of elective subjects for more thorough acquaintance of students with the features of future coaching activities; to increase the hours allotted for independent work and to introduce the newest means of control over its carrying out; apply modern pedagogical and information technologies that help bring the educational process closer to future coaching activities; to develop new professionally oriented disciplines and their educational and methodical support; to modernize the existing teaching methods.

The personal approach in the context of higher education allows to direct the educational process on the development of the personality of the future specialist in physical culture and sports; direct the efforts of teachers to become a future specialist in physical culture and sports as a person in the process of involving a 
sports coach; emphasize the subjective role of the student in the learning process; to create conditions for selfrealization and self-development of the personality of the future specialist in physical culture and sports.

The modular approach to learning provides an opportunity to gradually develop students' abilities to conduct coaching activities; take into account the cognitive and personal characteristics of future specialists in physical culture and sports and implement them in solving certain didactic tasks; to lay in students an approximate basis and algorithm for performing professional actions.

The theoretical concept of the study involves determining the basic definitions of the educational component of psychological training of future professionals in physical culture and sports to the activities of a sports coach in higher education; clarification of pedagogical conditions of effective psychological training of future specialists in physical culture and sports for the activity of a sports coach in higher education institutions.

The methodical concept of the research provides methodical support of psychological training of future specialists in physical culture and sports for the activity of a sports coach in higher education institutions.

The general hypothesis is based on the statement that the training of physical education personnel in higher education institutions will be high quality and successful, if in the process of professional training to implement a developed and theoretically sound method of psychological training of future specialists in physical culture and sports.

In developing methods of psychological training of future specialists in physical culture and sports for the activities of a sports coach in higher education, we focused on existing approaches to the implementation of the educational process using pedagogical technologies, theoretical and methodological provisions on the organization of training, analysis materials the state of the problem we are studying.

The purpose of the methodology developed by us is the organization of psychological training of future specialists in physical culture and sports for the activities of a sports coach in higher education institutions. Achieving this goal is ensured through the solution of such tasks as:

1) training in knowledge about the content of the professional activity of a sports coach;

2) training in ways to overcome these situations;

3) development of intellectual abilities;

4) the formation of skills and abilities to solve problems facing the coach in the field of sports.

The leading idea of our methodology is the provision that modeling professional activities during theoretical and practical classes based on a set of intellectual tasks can contribute to the formation of psychological readiness of future professionals in physical culture and sports to work as a sports coach in higher education. Modeling promotes the transition of subject (objective) knowledge in the form of the internal position of the individual (subjective knowledge and experience).

Knowledge of the content of the professional activity of a coach in the field of sports, ways to solve professional problems does not fully ensure the student's readiness to implement them in practice. Skills and abilities of organizing the professional activity of a sports coach in the conditions of higher education institutions do not guarantee their successful use in the conditions of professional activity of a sports coach. Therefore, a necessary technological condition for the implementation of the leading idea is to adhere to a strict sequence in the assimilation of educational material: the development of the studied information formation of skills to use this material, the formation of skills to act adequately in professional activities.

In developing the methodology, we took into account the existence of a direct link between the formation of internal motivational relations of the future specialist in physical culture and sports to the activities of a sports coach and the activity of his mental processes and practical actions to overcome them. Motivation of professional training is a guarantee of strong assimilation of educational material, as a motivated attitude to the process of professional training always contributes to the mobilization of internal cognitive activity. However, depending on the results of this activity to a greater or lesser extent there are positive changes in the mental properties and behavior of the subject of training.

\section{Results}

Psychological training of future specialists in physical culture and sports for the activity of a sports coach is carried out through a consistent movement of educational levels: the level of motivation for professional training for the activity of a sports coach, the level of theoretical experience, the level of practical experience. 
The level of motivation for professional training for the activity of a sports coach is the initial stage of professional training. It carries out the process of forming a motivated attitude of the future specialist in physical culture and sports to professional training to perform the professional duties of a sports coach, information about which is passed to the future specialist from the teacher.

Analysis and synthesis, generalization and specification of this information lead to its translation into subjectively significant knowledge. Understanding the personal significance of information about the professional activities of a sports coach and the ability to solve all professional titles becomes one of the decisive factors in the formation of a lasting interest in professional development. Thus, the processes of motivation, comprehension and acceptance of educational information are realized.

The level of theoretical experience is aimed at the theoretical development of educational material. The imaginary solution of professional tasks, the search for optimal actions aimed at successfully solving the tasks, determine the bright emotionality and high level of intellectual activity of the future specialist in physical culture and sports. Complexity, but the availability of educational tasks of a problematic nature create conditions not only for the acquisition of special knowledge, but also for the development of intellectual abilities of the future specialist. The situation of joint discussion and evaluation of the student's decision, analysis of possible predicted scenarios, ideas of coaching, psychological and emotional reactions and their actions in terms of solving professional problems contribute to the formation of theoretical experience of a coach in sports.

The level of practical experience is aimed at the practical development of educational material. On the basis of already known information about specific responsibilities in the professional activity of a sports coach (theoretical development), the future specialist in physical culture and sports practically uses the available theoretical experience. This creates conditions for the formation of skills to rationally use their knowledge during professional activities. The practical implementation of actions aimed at solving the problems of professional activity of a sports coach in the conditions of professional training in higher education institutions contributes to the formation of special skills and abilities.

Implementation of the developed methods of psychological training of future specialists in physical culture and sports to the activities of a sports coach was carried out during theoretical and practical classes in the disciplines «Introduction to the specialty», "Theory and methods of physical education», "Theory and methods of gymnastics», "Fundamentals sports training», "Olympic and professional sports» and coaching practice.

The purpose of teaching disciplines is to form in students the general foundations of the theory and methods of physical education, physical culture and sports that extend to a wide range of applications (sports, basic physical culture, health physical culture for people of different ages). Disciplines are focused on the generalization of specific theoretical and methodological patterns of physical education, which are considered in the structure of medical, biological, sports, pedagogical, psychological, pedagogical, social disciplines, as well as physical culture and sports.

The organization of psychological training of future specialists in physical culture and sports for the activities of a sports coach was carried out during practical classes in professional disciplines and includes the following components:

- forms of the system of formation of psychological readiness of future specialists in physical culture and sports to the activity of a coach in sports - lectures, seminars, coaching practice, collective, group and independent classroom work of students, competitions, scientific conferences of students;

- methods - interactive educational technologies, business games, which involve future professionals in physical therapy and occupational therapy professional tasks and responsibilities, problem-oriented learning, project-oriented learning, team-oriented learning;

- means - means of physical education and sports training, textbooks, manuals, test tasks, means of information and communication technologies.

The results of students' study of professional disciplines are the readiness of future specialists in physical culture and sports:

1) to analyze social processes in the field of physical culture and sports, to demonstrate their own vision of ways to solve existing problems;

2) process data using modern information and communication technologies; 
3) master new professional information, evaluate and present their own experience, analyze and apply the experience of colleagues;

4) have basic knowledge of research on the problems of physical culture and sports, preparation and design of scientific work;

5) to carry out training of motor actions and development of motor qualities of the person in the conditions of various forms of the organization of employment by physical exercises;

6 ) demonstrate readiness to strengthen personal and public health through the use of physical activity and other factors of a healthy lifestyle, conducting outreach work among various groups of the population;

7) evaluate the motor activity of a person and his physical condition, compile and implement fitness training programs, organize and conduct physical culture and health activities;

8) substantiate the choice of measures for physical culture and sports rehabilitation and adaptive sports;

9) to determine the functional state of the human body and justify the choice of means of prevention of overstrain of the body systems of persons engaged in physical culture and sports;

10) to argue management decisions to solve problems that arise in the work of subjects of physical culture and sports; have leadership skills.

The purpose of coaching practice is for students to master modern tools, methods and forms of organizing the work of a coach in the chosen sport, forming on the basis of acquired knowledge, skills and abilities necessary for professional activity, making independent decisions, educating the constant need to systematically update their knowledge and creativity. as well as its implementation in practice.

This goal is achieved by:

- acquaintance of students with the structure and content of work in sports organizations (sports children's and youth schools of the Olympic reserve, children's and youth sports schools, schools of higher sportsmanship, sports clubs), which are the bases of practice;

- creating a holistic view of the content and nature of coaching (organizational, educational, training, coaching, research, administrative, judicial and representative);

- formation of stable skills in the organization and practical application of modern scientific and methodological arsenal, including means of training, education, rehabilitation, as well as special physical, technical and tactical training;

- teaching students the leading technologies of planning, modeling, programming, correction of training influences, as well as control and evaluation of the effectiveness of their own coaching activities.

Tasks of coaching practice:

1. Formation of professional skills and abilities in relation to the practical orientation of the training process.

2. Study of the structure and content of the coach's work in various levels of training athletes in Ukraine, namely: sports section; children's and youth sports school; specialized children's and youth sports school; Olympic reserve training schools; schools of higher sportsmanship; Olympic training centers and national teams; other sports organizations.

3. Preparing students for independent work as a coach in the chosen sport. athletes.

4. Getting a complete picture of the content and nature of coaching at different stages of training

5. Formation of skills in the organization, planning, training and coaching process, control over it and the organization of competitive activities of athletes.

6. Acquaintance with the structure, forms, methods and content of sports organizations (objects of practice) on the basis of studying the regulatory, organizational, financial documentation and conducting interviews with the management of organizations.

The responsibility for the general organization of the practice and control over its implementation rests with the head of the coaching practice of the university. The head of the internship receives and evaluates the students' reports on the internship. Based on this, he makes assessments.

The head of the coaching practice of the university controls the readiness of the practice base before the beginning of its implementation, ensures the necessary organizational measures: instructing teachers on the procedure of practice, providing students with the necessary documentation, etc. Educational and 
methodical support of coaching practice is provided by subject commissions of professional departments of physical education and sports.

Experienced teachers of departments and leading specialists from the bases of practice are involved in the methodical guidance of students' coaching practice: coaches, methodologists of children's and youth sports schools. The teacher of the department - the head of practice together with the trainer from base of practice provide high quality of performance by each student of the program of practice. They control the provision of normal working and living conditions for students, conduct mandatory training with them on labor protection and safety, conducting training and coaching classes, monitor students' compliance with internal regulations, keep a log of coaching practice.

Content of students' activities and forms of reporting on practice:

1. Make an individual work plan.

2. Make an annual plan of the training process (macrocycle).

3. Make a plan of the training process for the period of practice (mesocycle).

4. Keep a log of the training group.

5. Make ten summaries of training sessions of full content.

6. Conduct 10 training sessions on the sport.

7. Make a report on the coaching practice.

During the coaching practice, students are required to complete all sections of the program in accordance with their individual plan. The calculation of hours for individual educational tasks is adjusted taking into account the personal experience of the student, his acquired skills, abilities and knowledge.

In the training process with attached groups, students focus on the work plans of practice base trainers.

At the same time, each trainee must show personal initiative and creativity, avoid pattern and formalism in the content, organization and methodology of training sessions and other physical culture and sports activities held outside of school hours.

To this end, the trainee is obliged to:

- to diversify the content of classes;

- to apply various methods of the organization of employment and methods of training, to use more widely competitive, group, individual and other methods of carrying out of training employment;

- conduct classes of various types and forms;

- take part in advocacy work with children, coaching staff, in the design of information stands, etc .;

- to introduce advanced scientific and information technologies into the training process.

List of documents submitted for the defense of practice:

1. Individual work plan.

2. Annual plan of the training process (macrocycle).

3. Plan of the training process for the period of practice (mesocycle).

4. Journal of the work of the training group.

5. Ten summaries of full training sessions.

6. Report on coaching practice.

\section{Discussion}

Theoretical analysis of modern research and own pedagogical experience made it possible to establish that a person must be psychologically ready for any activity, which determines the process of creating a person's readiness for productive participation in it. Strengthening the role of psychology in modern sports provides for the need for psychological training not only for the athlete, but also for the coach. For a coach, who is in charge of the pedagogical process, psychological training is no less important than for an athlete [7, 10, 21].

In the field of sports, there is an opinion that both the coach and the athlete themselves must perform the functions of a psychologist. Due to the increasing importance of the psychological factor in the training of athletes, the coach also solves a number of psychological problems: for example, direct control of an athlete before the start (second), creating conditions for the formation of a personality in sports, taking into account the physiological and psychological characteristics of the athlete's personality $[4,25]$. Success in sports largely 
depends on the nature of the existing relationship between the coach and the athletes, the high cohesion of the team, and on the style of leadership $[5,6,12]$. This is not a complete list of tasks that a coach has to face.

However, as practice shows, a psychologist must solve serious psychological problems. In addition, we must not forget that during the performances of athletes, the coach often more needs to regulate the emerging unfavorable mental states, since the experiences become overly violent, thereby negatively affecting the performance of the athlete [11]. During the competition, an athlete is especially susceptible to all external influences, therefore, it is important for a coach to be able to manage his emotions in order to provide a psychological impact on athletes, to maintain their confidence in their strengths and the will to win. In this process, a sports psychologist can provide a coach with some assistance, organize his psychological training $[20,28]$.

Psychological preparation for the professional activity of a trainer is the process of forming a system of mental formations (processes, states and personality traits) that determine personal readiness and the ability to solve pedagogical problems (implementation of the functions of training and education). The final and natural result of the process of psychological training of a coach is the formed professional readiness for pedagogical and coaching activities [14].

Tasks:

- Formation of the professional competence of the coach;

- improving the psychological culture of the coach;

- formation of motivation for the pedagogical activity of the trainer;

- improving the professional qualities of the coach's personality;

- formation of an individual style of the coach's activity;

- the formation of skills for the regulation of adverse mental states;

- prevention of «emotional burnout» in the activities of a coach;

- the formation of favorable relationships in the systems: «coach - athlete», «coach - coach», «coach parent», «coach - psychologist».

There are two groups of difficulties in the activities of a trainer:

1) objective: insufficient assistance from the administration, colleagues; lack of material and technical means; lack of free time; the specificity of the sport, the location of the sports section, insufficient awareness of the population about the peculiarities of the sport.

2) subjective: insufficient level of knowledge of pedagogy, psychology, theory and methodology of the sport, physiology (unformed gnostic abilities); unformed organizational, communication skills (difficulties in establishing relationships with athletes and restructuring them in accordance with the development of pupils); difficulties in establishing relationships with parents, colleagues, administration; low level of planning and conducting classes (unformed design and constructive abilities); personal qualities (poorly developed volitional qualities, emotional immaturity, overestimation of one's strengths and capabilities, self-confidence, arrogance, rejection of the advice of experienced coaches or self-doubt); formal fulfillment of their duties, the manifestation of inattention to poorly trained athletes, failure to fulfill their promises, excessive pickiness; insufficient level of education and general culture of the coach, indiscipline, violation of the norms and rules of ethics, the desire to gain authority at any cost; inability to manage their mental states, especially in difficult competition conditions [9].

Difficulties are overcome in various ways. So, subjective difficulties can be overcome only with certain knowledge, skills and abilities in solving this type of special and educational tasks, a high level of skill. Objective difficulties are overcome with the involvement of the administration and the public. Despite the age, gender, pedagogical experience, in the first place is the difficulty of managing the formation of an athlete's personality. It is largely determined by the complexity of the interaction in the "coach - athlete» system [14].

Professional readiness is considered as a subjective state of a person who considers himself capable and prepared to perform a certain professional activity and strives to perform it.

The main condition for the formation of students' professional readiness is their mastery of the ability to manage themselves (mental transfer, self-instruction, self-order).

In modern concepts of pedagogical education, there are tendencies of a creative approach to technology, forms, methods in training specialists in physical culture and sports, teaching students. The essence of our problem lies in ensuring the readiness of students of the Faculty of Physical Culture and Sports 
not only for the main specialty of a teacher of physical culture, but also for professional activities as a teacher of health-improving, correctional and other orientation. Consequently, a future professional must have all types of readiness, including psychological $[8,22]$.

The introduction of practical tasks arising in the professional activity of a trainer into the process of professional training determines the whole variety of techniques and methods of pedagogical interaction, their effectiveness and acceptability by students. The professional growth of a coach in a sport is impossible without the development of his professional culture or creative possibilities. These factors, on the one hand, are implicitly present and have a different representation, both in the structure of professionally important personality traits and in the structure of professional activity $[22,24,28]$. They are manifested in the selfdevelopment of the individual; in self-knowledge and self-assessment of a set of professionally necessary qualities; in realizing the contradictions between the modern functions of a coach and the level of his development; in the progressive transformation of the training process; in systematic self-educational and selfeducational activities; in predicting the characteristics of their development in professional activity; in focus on active work with athletes, on taking care of their development.

\section{Conclusion}

Thus, in developing the methodology, we took into account the existence of a direct link between the formation of internal motivational relations of the future specialist in physical culture and sports to the activities of a sports coach and the activity of his mental processes and practical actions to overcome them.

Methods of psychological training of future specialists in physical culture and sports for the activities of a sports coach in higher education institutions involves a consistent movement of educational levels: the level of motivation for training for the activities of a sports coach, the level of theoretical experience, the level of practical experience.

Implementation of the developed methods of psychological training of future specialists in physical culture and sports to the activities of a sports coach was carried out during theoretical and practical classes in the disciplines "Introduction to the specialty», "Theory and methods of physical education», "Theory and methods of gymnastics», «Fundamentals sports training», "Olympic and professional sports» and coaching practice.

During the coaching practice, students are required to complete all sections of the program in accordance with their individual plan. In the training process with attached groups, students focus on the work plans of practice base trainers. Each student must show personal initiative and creativity, avoid pattern and formalism in the content, organization and methodology of training sessions and other physical culture and sports activities held outside of school hours. To this end, the trainee is obliged to: diversify the content of classes; apply various methods of organizing classes and teaching methods, more widely use competitive, group, individual and other methods of training; to conduct classes of different types and forms; to take part in propaganda work with children, coaching staff, in the design of information stands; to introduce advanced scientific and information technologies into the training process.

A necessary technological condition for the implementation of the leading idea is the observance of strict sequence in the assimilation of educational material: the development of the studied information, the formation of skills to use this material, the formation of skills to act adequately in professional activities.

The organization of psychological training of future specialists in physical culture and sports for the activity of a sports coach was carried out during practical classes in professional disciplines and includes the following components: forms of system of psychological readiness of future specialists in physical culture and sports for sports coach - lectures, seminars, coaching practice, collective, group and independent classroom work of students, competitions, scientific conferences of students; methods - interactive educational technologies, business games, which involve the performance of future specialists in physical therapy and occupational therapy professional tasks and responsibilities, problem-oriented learning, project-oriented learning, team-oriented learning; means - means of physical education and sports training, textbooks, manuals, test tasks, means of information and communication technologies.

Prospects for further research are issues related to determining the level of psychological readiness of future specialists in physical culture and sports to both coaching and activities in the field of physical culture and sports in general. 


\section{References}

1. Crust, L., Clough, P. (2011). Developing mental toughness: From research to practice. Journal of Sport Psychology in Action, 2, 21-32.

2. Curry, L., Maniar, S. (2003). Academic Course Combining Psychological Skills Training and Life Skills Education for University Students and Student-Athletes. Journal of Applied Sport Psychology, 15. 270-277. doi: 10.1080/10413200305384.

3. Danylevych, M. (2018). Professional training of future specialists in physical education and sports for recreational and health activities: theoretical and methodological aspect [Profesiina pidhotovka maibutnikh fakhivtsiv z fizychnoho vykhovannia ta sportu do rekreatsiino-ozdorovchoi diialnosti: teoretyko-metodychnyi aspekt]: monograph. LA «Piramida», Lviv, 460. [in Ukrainian]

4. Driska, A., Kamphoff, C., Armentrout, S. (2012). Elite swimming coaches' perceptions of mental toughness. The Sport Psychologist, 26, 186-206.

5. Ghasemi, A., Yaghoubian, A., Momeni, M. (2012). Mental toughness and success levels among elite fencers. Advances in Environmental Biology, 6(9), 2536-2540.

6. Gordon, S. (2012). Strengths-based approaches to developing mental toughness: Team and individual. International Coaching Psychological Review, 7(2), 210-222.

7. Gucciardi, D. (2012). Measuring mental toughness in sport: A psychometric examination of the Psychological Performance Inventory-A and its predecessor. Journal of Personality Assessment, 94(4), 393-403.

8. Gucciardi, D., Gordon, S., Dimmock, J. (2008). Towards an understanding of mental toughness in Australian football. Journal of Applied Sport Psychology, 20, 261-281.

9. Gucciardi, D., Gordon, S. Dimmock, J. (2009). Advancing mental toughness research and theory using personal construct psychology. International Review of Sport and Exercise Psychology, 2, 54-72.

10. Hill, D. M., and Shaw, G. (2013). A qualitative examination of choking under pressure in team sport. Psychol. Sport Exerc., 14, 103-110. doi: 10.1016/j.psychsport.2012.07.008

11. Jones, G., Hanton, S., Connaughton, D. (2002). What is this thing called mental toughness? An investigation into elite performers. Journal of Applied Sport Psychology, 14, 205-218.

12. Mahoney, J. Gucciardi, D., Ntoumanis, N., Mallet, C. (2014). Mental toughness in sport: Motivational antecedents and associations with performance and psychological health. Journal of Sport and Exercise Psychology, 36(3), 281-292.

13. Medynskyi, S. (2016). Content of professional training of specialists in physical education and sports in the USA [Zmistove napovnennia profesiinoi pidhotovky fakhivtsiv fizychnoho vykhovannia i sportu v SShA]. Scientific journal of the National Pedagogical Dragomanov University. Series № 15. Scientific and pedagogical problems of physical culture (physical culture and sports), 8(78)16, 54-56. [in Ukrainian]

14. Melnyk, E.V., Sylych, E. V., Kukhtova, N. V. (2014). Trainer psychology: theory and practice: guidelines [Psykholohyia trenera: teoryia y praktyka: metodycheskye rekomendatsyy]. VHU ymeny P.M. Masherova, Vitebsk, 58. [in Russian]

15. McEwan, D., Beauchamp, M. R. (2014). Teamwork in sport: a theoretical and integrative review. Int. Rev. Sport Exerc. Psychol., 7, 229-250. doi: 10.1080/1750984X.2014.932423

16. Morgan, P. B. C., Fletcher, D., Sarkar, M. (2015). Understanding team resilience in the world's best athletes: a case study of a rugby union world cup winning team. Psychol. Sport Exerc., 16, 91-100. doi: 10.1016/j.psychsport.2014.08.007

17. Olusoga, P., Maynad, I., Butt, J., Hays, K. (2014). Coaching under pressure: Mental skills training for sports coaches. Sport and Exercise Psychology Review, 10(3), 31-4.

18. Parkes, J., Mallet, C. (2011). Developing mental toughness: Attributional style retraining in rugby. The Sports Psychologist, 25(3), 269-287.

19. Prytula, A.L.. (2015). Professional training of physical culture teachers for use in national martial arts career. Pedagogics, psychology, medical-biological problems of physical training and sports, 19, 62-67. doi: 10.15561/18189172.2015.0112.

20. Slack, L., Maynard, I., Butt, J., Olusoga, P. (2015). An evaluation of a mental toughness education and training program for early-career English football league referees. Sport Psychologist, 29(3), 237-257.

21. Smith, B., McGannon, K. R. (2018). Developing rigor in qualitative research: problems and opportunities within sport and exercise psychology. Int. Rev. Sport Exerc. Psychol., 11, 101-121. doi: 10.1080/1750984x.2017.1317357

22. Sushchenko, L. P. (2000). Professional training of future specialists in physical education and sports: information aspect [Profesiina pidhotovka maibutnikh fakhivtsiv fizychnoho vykhovannia ta sportu :informatsiinyi aspekt]. Pedagogy. Scientific works, 7, 122-126. [in Ukrainian]

23. Svistelnyk, I. R. (2007). Higher physical education: trends in information development [Vyshcha fizkulturna osvita: tendentsii informatsiinoho rozvytku]. Theory and methods of physical education, 4, 8-10. [in Ukrainian]

24. Temerivska, T. H. (2010). The state of readiness of students of the Faculty of Physical Culture and Human Health for future professional activity [Stan hotovnosti studentiv fakultetu fizychnoi kultury ta zdorov'ia liudyny do maibutnoi profesiinoi diialnosti]. Pedagogics, psychology, medical-biological problems of physical training and sports, 11, 123-124. [in Ukrainian]

25. Van Dinther M., Dochy F., Segers M., Braeken J. (2013). The construct validity and predictive validity of a selfefficacy measure for student teachers in competence-based education. Studies in Educational Evaluation, 39(3), 169-179. doi:10.1016/j.stueduc.2013.05.001. 
26. Weinberg, R., Butt, J., Culp, B. (2011). Coaches' views of mental toughness and how it is built. International Journal of Sport and Exercise Psychology, 9(2), 156-172.

27. Weinberg, R., Freysinger, V., Mellano, K., Brookhouse, E. (2016). Building mental toughness: Perceptions of sport psychologists. Sport Psychologist, 30(3), 231-241.

28. Wergin, V. V., Mallett, C. J., Mesagno, C., Zimanyi, Z., Beckmann, J. (2019). When You Watch Your Team Fall Apart Coaches' and Sport Psychologists' Perceptions on Causes of Collective Sport Team Collapse. Front. Psychol., 10:1331. doi: 10.3389/fpsyg.2019.01331

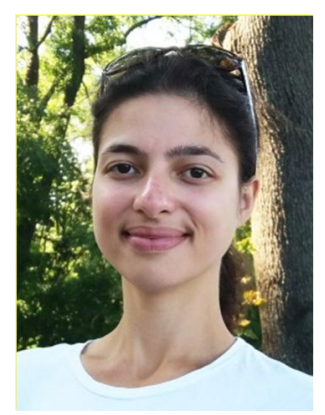

Дмітрієва Ніколь Субханівна.

Магістрантка,

Національний педагогічний університет імені М. П. Драгоманова,

вул. Пірогова, 9, м. Київ, Україна, 01601.

Tel. +38(067)765-61-99. E-mail: nikolestern@ukr.net.

\section{Dmitriieva Nikol Subkhanivna,}

Master's student,

National Pedagogical Dragomanov University,

Pyrogova st., 9, Kyiv, Ukraine, 01601.

Tel. +38(067)765-61-99. E-mail: nikolestern@ukr.net.

ORCID: 0000-0001-6492-3371

Researcher ID: AAC-4564-2019

\section{Citation (APA):}

Dmitriieva, N. (2021). Psychological training of future specialists in physical culture and sports for the activities of a sports coach in higher education institutions. Engineering and Educational Technologies, 9 (1), 90-101. doi: https://doi.org/10.30929/23079770.2021 .09 .01 .08

\section{Цитування (ДСТУ 8302:2015):}

Дмітрієва Н. С. Психологічна підготовка майбутніх фрахівців з фізичної культури і спорту до діяльності тренера з виду спорту у закладах вищої освіти / Інженерні та освітні технології. 2021. Т. 9. № 1. С. 90-101. doi: https://doi.org/10.30929/23079770.2021 .09 .01 .08

Обсяг статті: сторінок - 12; умовних друк. аркушів - 1,738. 